ДИЛЕМА ЕФЕКТИВНОСТІ ВИРОЩУВАННЯ ОЛІЙНИХ КУЛЬТУР
ТА ЗБЕРЕЖЕННЯ РОДЮЧОСТІ В УМОВАХ СТАНОВЛЕННЯ РИНКУ ЗЕМЛІ

\title{
THE DILEMMA OF THE EFFICIENCY OF OIL CROPS CULTIVATION AND SUSTAINING THE PRODUCTIVITY IN THE CONDITIONS OF THE LAND MARKET FORMATION
}

удк 332

https://doi.org/10.32843/infrastruct36-24

Ковальова О.М.

к.е.н., доцент,

доцент кафредри економіки

та підприємництва

Сумський національний

аграрний університет

Кравченко К.В.

магістрант

Сумський національний

аграрний університет

Пшикало В.С.

магістрант

Сумський національний

аграрний університет

\begin{abstract}
у статті розглянуто ефрективність вирощування олійних культур в окремому сільськогосподарському підприємстві та Україні загалом. Аналіз показав, що ефективність вирощування цих культур є досить високою, однак намітилася тенденція до зниження рівня рентабельності. Причиною $є$ збільшення витрат на хімічні засоби для збільшення урожайності. Така ситуація зумовлена недотриманням товаровиробниками умов раціонального ведення сільськогосподарської діяльності, зокрема перевищенням частки виснажливих культур у сівозміні, в результаті чого родючість зменшується. Для вирішення дилеми підвищення есрективності вирощування олійних культур та збереження родючості грунтів слід запровадити системи постійного державного контролю за станом родючості земель, дотриманням землекористувачами та власниками земель вимог раціонального землекористування. Також слід упровадити системи сертифрікації та екологічного маркування всіх хімічних засобів, що використовуються в сільському господарстві. Такі заходи є першочерговими перед відкриттям ринку земель.

Ключові слова: ефективність вирощування олійних культур, збереження родючості, державний контроль якості земель, екологічне маркування, ринок сільськогосподарських земель
\end{abstract}

В статье рассмотрена эфроективность выращивания масличных культур в отдель- ном сельскохозяйственном предприятии и Украине в целом. Анализ показал, что эфррективность выращивания этих культур является довольно высокой, однако наметилась тенденция к снижению уровня рентабельности. Причиной является увеличение затрат на химические средства для увеличения урожайности. Такая cumyация обусловлена несоблюдением товаропроизводителями условий рационального ведения сельскохозяйственной деятельности, в частности превышением в севообороте доли культур, истощающих почву, в результате чего плодородие уменьшается. Для решения дилеммы повышения эфорективности выращивания масличных культур и сохранения плодородия почв следует ввести системы постоянного государственного контроля за состоянием плодородия земель, соблюдением землепользователями и собственниками земель требований рационального землепользования. Также следует внедрить системы сертификации и экологической маркировки всех химических средств, используемых в сельском хозяйстве. Такие меры являются первоочередными перед открытием рынка земель.

Ключевые слова: эфффективность выращивания масличных культур, сохранение плодородия, государственный контроль качества земель, экологическая маркировка, рынок сельскохозяйственных земель.

Oilseeds are of great nutritional and technical importance. They are used as a food product in kind, for the manufacture of margarine, in the canning, food and confectionery industries. Due to the large economic, agro-technical and economic importance of oilseeds, the demand for these crops has increased significantly in recent years and has led to high prices for these seeds in Ukraine, which ensures high incomes of farmers and foreign currency to Ukraine. However, the question of further improving the efficiency of oilseed production, especially sunflower, and preserving the fertility of the land remains urgent. An analysis of the efficiency of growing oilseeds has shown that their production is effective, both in a single enterprise and in Ukraine as a whole. However, there has been a recent trend of declining performance indicators, including profitability. One of the reasons for this is the deterioration of fertility due to the irrational use of land by domestic land users, in particular, the excess of the share of depleting crops in the structure of acreage over the recommended norms, failure to observe crop rotation. That being the case, to maintain the achieved level and to further increase the yield, producers had to apply larger doses of mineral fertilizers, which firstly may affect the level of land pollution and, secondly, increases the cost, resulting in a decreased profitability. Thus, in order to resolve the dilemma of improving the efficiency of oilseeds production and preserving fertility, a state control system for soil fertility should be introduced. Such controls should be carried out regularly by the special state bodies at regular intervals and without notification to the owner or land user. It is also important to enshrine at the statutory level the necessity to comply with rationally justified crop rotations for the land users. In the structure of sown areas share depleting crops must not exceed 15\%, this should also be followed by the relevant public authorities. In addition, all chemicals used in crop production must be certified and properly labelled for their harm to soil and farm animals and insects. The introduction of appropriate regulations on the rational use and conservation of land fertility is a priority before the creation of the land market in Ukraine.

Key words: oil crops growing effectiveness, sustaining fertility, state control over land quality, eco-labelling, agricultural land market.

Постановка проблеми: Олійні культури мають велике харчове й технічне значення. Їх використовують як харчовий продукт у натуральному вигляді, для виготовлення маргарину, в консервній, харчовій і кондитерській промисловості. Цінність харчової рослинної олії зумовлена вмістом у ній біологічно активних жирних кислот, які організмом людини не синтезуються, а засвоюються тільки в готовому вигляді. Олію використовують також в електротехнічній, шкіряній, металообробній, хімічній, текстильній та інших галузях промис- ловості; ефрірну олію - у фрармацевтичній, парфрумерній, кондитерській промисловості. Побічні продукти переробки насіння олійних культур (макуха і шрот) - цінний концентрований корм для тварин, що містить 35-40\% білка. Значну кількість олійних рослин вирощують як просапні культури, тому вони мають агротехнічну цінність - $є$ добрими попередниками для наступних культур сівозміни, особливо зернових хлібів [1].

Завдяки великому господарському, агротехнічному та економічному значенню олійних культур 
в останні роки значно зріс попит на ці культури і спричинив високі ціни на насіння цих культур в Україні, що забезпечує високі доходи сільськогосподарських виробників та надходження валютних коштів в Україну. 3 огляду на значення олійних культур для економіки країни загалом та окремих виробників, необхідно постійно здійснювати аналіз ефективності виробництва продукції олійних культур з метою виявлення резервів її подальшого підвищення.

Аналіз останніх досліджень і публікацій. Дослідженню проблем у галузі економіки олієсировинного виробництва присвячені публікації зарубіжних учених: І. Бенента, В.А. Тихонова, О. Єскараєва, а також українських економістіваграрників - В.В. Лазні, П.М. Макаренка, І.І. Лукінова, О.М. Шпичака, В.В. Юрчишина, П.Т. Саблука, Д.І. Нікітчина, В.М. Петрова, С.О. Тивончука, О.П. Антонюка [2], Л.А. Бахчиванжи [3] та інших. Однак ще залишилися невирішеними деякі питання щодо подальшого підвищення ефективності виробництва олійних культур, зокрема питання одночасного вирощування олійних, особливо соняшнику, та збереження родючості землі.

Постановка завдання. Метою статті $€$ проведення аналізу виробництва олійних культур у сільськогосподарському підприємстві та в Україні; виявлення основних шляхів підвищення економічної ефективності виробництва олійних культур; дослідження проблеми вибору між високою доходністю від виробництва олійних культур та збереженням родючості землі.

Виклад основного матеріалу дослідження. До олійних належать культури, в насінні або плодах яких міститься не менш як 15\% олії. Таких рослин, що належать до різних ботанічних родин, налічується понад 340. Головними польовими олійними культурами у світі $€$ соя, ріпак, соняшник, арахіс, бавовник, льон кудряш, кукурудза. Найбільшим виробником соєвих бобів та соєвої олії $€$ США. Ця олія виробляється також у Китаї, Японії, Канаді, Бразилії, Індонезії. Соняшник вирощується головним чином у Росії, Україні, Франції, Угорщині, Румунії, Аргентині, США, Китаї. Найбільшими виробниками соняшникової олії є Аргентина, Росія та Україна, а також США, Туреччина, Індія. В Україні соняшник вирощується практично по всій території (крім Полісся), проте найкращі умови у Дніпропетровській, Запорізькій, Донецькій областях. Ріпак вирощується у Польщі, Угорщині, Україні, країнах північної Європи, США, Канаді, Китаї. Найбільшим експортером ріпакового насіння та олії є Канада [4]. Також Україна сьогодні займає одне 3 провідних місць серед соняшникосіючих держав, забезпечуючи 7\% світового виробництва насіння соняшнику. У 2017-2018 маркетинговому році Україна стала лідером серед світових експортерів соняшнику, забезпечивши 29\% світового експорту [5].

Внаслідок встановлення сприятливої цінової ситуації на ринку олійних культур сьогодні їх вирощуванням займаються більшість сільськогосподарських підприємств України. Проаналізуємо галузь виробництва олійних культур в одному з сільськогосподарських підприємств Сумської області.

Посівні площі під сільськогосподарськими культурами є одним із важливих фракторів, що впливають на обсяги валових зборів продукції олійних культур. Від структури посівних площ залежить процес чергування культур у сівозміні, що впливає на родючість землі (табл. 1).

Дані таблиці 1 свідчать, що частка олійних культур в підприємстві зменшилася 3 52,5\% у 2016 році до $39,8 \%$ у 2018 році, що сталося через зменшення частки сої майже у чотири рази. Однак частка соняшнику, який є самою виснажливою культурою, зросла з 19,2\% у 2016 році до $22,4 \%$ у 2018 році. В Україні загалом частка олійних культур дещо зросла, а саме на 1 процентний пункт, і становила у 2018 році 32,1\%. Структура площ під олійними культурами залишилася майже незмінною. Слід відмітити, що як на підприємстві, так і в Україні загалом частка соняшнику є надмірною. Так, за даними агрономічної науки його питома вага в структурі посівних площ не повинна перевищувати 14\% [8]. Як бачимо, фактичні дані значно перевищують цей норматив. Така ситуація шкідливо впливає на стан ґрунтів.

Таблиця 1

Структура посівних площ, \%

\begin{tabular}{|l|c|c|c|c|c|c|}
\hline \multirow{2}{*}{ Групи і види культур } & \multicolumn{3}{|c|}{ Підприємство } & \multicolumn{3}{c|}{ Україна } \\
\cline { 2 - 7 } & $\mathbf{2 0 1 6}$ р. & $\mathbf{2 0 1 7}$ p. & $\mathbf{2 0 1 8}$ p. & $\mathbf{2 0 1 6}$ p. & $\mathbf{2 0 1 7}$ p. & $\mathbf{2 0 1 8}$ p. \\
\hline Зернові і зернобобові - всього & 47,5 & 63,1 & 60,2 & 53,3 & 53,0 & 53,6 \\
\hline Олійні культури & 52,5 & 36,9 & 39,8 & 31,1 & 32,1 & 32,1 \\
\hline соняшник & 19,2 & 13,5 & 22,4 & 22,5 & 21,9 & 22,1 \\
\hline соя & 32,1 & 23,4 & 7,8 & 6,9 & 7,3 & 6,2 \\
\hline льон-довгунець насіння & 1,2 & - & - & 0,007 & 0,007 & 0,004 \\
\hline ріпак озимий & - & - & 9,6 & 1,7 & 2,9 & 3,8 \\
\hline Інші культури & - & - & - & 15,6 & 14,9 & 14,3 \\
\hline Посівна площа & 100 & 100 & 100 & 100 & 100 & 100 \\
\hline
\end{tabular}

Джерело: розрахованими за даними звітності підприємства та даними Державної служби статистики [6; 7] 
Однак сучасні вітчизняні сільськогосподарські товаровиробники не піклуються про якість землі, опікуючись лише збільшенням виробництва рентабельних культур, для чого й збільшують посівні площі під соняшником.

Наступним кроком є аналіз урожайності олійних культур (табл. 2).

Дані таблиці 2 свідчать, що урожайність соняшнику на підприємстві зменшилася майже на 10\% і становила у 2018 році 31,3ц/га, однак досягнутий рівень урожайності в підприємстві є набагато вищим, а саме на 25\%, ніж у середньому в Україні, де урожайність соняшнику становила за аналізований період 20-23 ц/га. Урожайність сої на підприємстві, навпаки, зросла на 29,2\% і становила у 2018 році 24,8 ц/га. Однак порівняно з Україною урожайність сої на підприємстві була меншою в кожному з аналізованих років. Також значно меншою, ніж в Україні, на підприємстві була урожайність ріпаку озимого, яка становила у 2018 році 22,9 ц/га, а в Україні в середньому за три роки понад 26 ц/га [6; 7].

Посівні площі та урожайність - це два основні фрактори, що впливають на обсяг валового збору сільськогосподарської продукції, що й проаналізуємо в таблиці 3.

Дані таблиці 3 свідчать, що валовий збір на підприємстві соняшнику та сої зменшився на 19,1\% та на 66\% відповідно. Валові збори обох культур змінилися під впливом обидвох чинників - і посівної площі, й урожайності. щодо соняшнику зменшилися і площа, і урожайність, під впливом чого зменшився валовий збір. За силою впливу обидва чинники виявилися приблизно однаковими, в результаті чого підприємство не добрало трішки більше ніж по 7000 центнерів, а загальні втрати насіння соняшнику становили 14859 центнерів.
Щодо сої за силою впливу сильнішим виявився чинник зменшення площі, в результаті чого підприємство недоотримало 76210 центнерів. Збільшення урожайності зумовило те, що підприємство мало додатковий валовий збір за рахунок цього фрактору в обсязі 21047 центнерів. Однак додаткового збору за рахунок зростання урожайності виявилося замало, щоб перекрити втрати продукції від зменшення площі. Причиною є більш швидкі темпи скорочення площі під соєю у 5 разів, ніж темп росту урожайності - всього на 30,5\%.

Загалом в Україні відмічаємо зростання валового збору сої, соняшнику та ріпаку. Причиною цього є як зростання урожайності, так і розширення посівних площ. Урожайність та площа льону-довгунцю, навпаки, зменшилися, що зумовило зменшення валового збору майже в 2 рази.

Ефективність виробництва - важлива категорія, оскільки дозволяє зіставити отриманий результат із понесеними затратами на виробництво продукції, тобто оцінити вигідність понесених затрат. Проведемо порівняльну характеристику ефективності виробництва олійних культур у досліджуваному підприємстві (табл. 4).

Дані таблиці 4 свідчать, що на I місці за показниками ефективності виробництва знаходиться ріпак. Він отримав перші місця за всіма показниками ефективності виробництва. За найнижчої 3-поміж трьох культур собівартості та найвищого рівня рентабельності ріпак має найбільшу різницю між ціною та собівартістю, що забезпечує найбільший прибуток на центнер та гектар площі. Таким чином, є найбільш привабливою культурою для виробництва в аналізованому підприємстві. На II місці знаходиться соя. Вона отримала три других та два третіх місця. На III місці знаходиться соняшник, який випередив сою лише за двома

Таблиця 2

Динаміка урожайності олійних культур

\begin{tabular}{|l|c|c|c|c|c|c|}
\hline \multirow{2}{*}{\multicolumn{1}{c|}{ Культури }} & \multicolumn{3}{|c|}{ Підприємство } & \multicolumn{3}{c|}{ Україна } \\
\cline { 2 - 7 } & $\mathbf{2 0 1 6 p .}$ & $\mathbf{2 0 1 7 p . ~}$ & $\mathbf{2 0 1 8 p .}$ & $\mathbf{2 0 1 6 p .}$ & $\mathbf{2 0 1 7 p . ~}$ & $\mathbf{2 0 1 8 p . ~}$ \\
\hline Соняшник & 34,5 & 30,9 & 31,3 & 22,4 & 20,2 & 23,0 \\
\hline Соя & 19,2 & 16,4 & 24,8 & 23,0 & 19,7 & 25,8 \\
\hline Льон-довгунець & 13,5 & - & - & 9,0 & 9,5 & 6,7 \\
\hline Ріпак озимий & - & - & 22,9 & 26,5 & 28,3 & 27,1 \\
\hline
\end{tabular}

Джерело: розрахованими за даними звітності підприємства та даними Державної служби статистики [6; 7]

Аналіз валового збору продукції олійних культур

Таблиця 3

\begin{tabular}{|l|c|c|c|c|c|c|}
\hline \multirow{2}{*}{ Культури } & \multicolumn{3}{c|}{ Підприємство, ц 2018p. } & \multicolumn{3}{c|}{ Україна, тис. тон } \\
\cline { 2 - 7 } & 2016p. & 2017p. & 2016. & 2017p. & 2018p. \\
\hline Соняшник & 77985 & 40420 & 63126 & 13626,9 & 12235,5 & 14165,2 \\
\hline Соя & 72573 & 36923 & 17410 & 4277,0 & 3899,4 & 4460,8 \\
\hline Льон-довгунець & 1910 & - & - & 1,3 & 1,3 & 0,7 \\
\hline Ріпак озимий & - & - & 19707 & 1153,9 & 2194,8 & 2750,6 \\
\hline
\end{tabular}

Джерело: розрахованими за даними звітності підприємства та даними Державної служби статистики [6; 7] 
Узагальнена порівняльна характеристика ефрективності вирощування олійних культур на підприємстві у 2018 році

\begin{tabular}{|l|c|c|c|c|c|c|}
\hline \multicolumn{1}{|c|}{ Показники } & Соняшник & Місце (ранг) & Соя & Місце (ранг) & Ріпак & Місце (ранг) \\
\hline Виробнича собівартість 1 ц, грн. & 803,5 & II & 883,6 & III & 685,6 & I \\
\hline Ціна 1ц, грн. & 860,8 & III & 977,8 & II & 1137,9 & I \\
\hline Прибуток на 1га, грн. & 4860,4 & II & 2415,1 & III & 9014,1 & I \\
\hline Прибуток на 1 ц, грн. & 251,4 & III & 319,4 & II & 439,0 & I \\
\hline Рівень рентабельності, \% & 41,2 & III & 48,5 & II & 62,8 & I \\
\hline Сума рангів & X & 13 & X & 12 & X & 5 \\
\hline Узагальнений ранг & X & III & X & II & X & I \\
\hline
\end{tabular}

Джерело: розрахованими за даними звітності підприємства

показниками: за собівартістю та сумою прибутку в розрахунку на гектар і має найнижчий рівень рентабельності серед трьох культур.

Аналогічно невисокий рівень рентабельності виробництва демонструють олійні культури і загалом вУкраїні, причому намітилася чітка тенденція до його зниження. Так, рівень рентабельності виробництва соняшнику у 2016 році становив 61,9\%, в 2017 році 41,3\%, в 2018 році - всього 32,5\% [6; 7]. щодо сої цей показник знизився з 28,8\% до 21,0\%, ріпаку - 3 43,6\% до 31,1\% у 2018 році.

Таким чином, констатуємо, що виробництво олійних культур є ефрективним, як загалом в Україні, так і в конкретному підприємстві. Однак останніми роками намітилася тенденція до зменшення показників ефективності.

Однією з причин погіршення $є$ те, що за останні 10 років значно розширилися посівні площі під олійними культурами, особливо під соняшником, зайнявши в структурі посівних площ понад 30\% загалом по олійних та понад 20\% по соняшнику, що $є$ неприпустимим з погляду агрономічної науки і що, звичайно, негативно позначається на родючості ґрунтів, зводячи до мінімуму кількість культур сівозміни. Урожайність якщо й зростає, то лише за рахунок внесення високих доз внесення мінеральних добрив, що також впливає на стан ґрунтів, збільшуючи їх забруднення.

Сучасні сільськогосподарські землекористувачі не дотримуються рекомендованих сівозмін для збереження родючості, оскільки, по-перше, їхньою метою $є$ отримання прибутку та швидке збагачення, а по-друге, більшість договорів оренди землі укладається терміном на п'ять років, чого недостатньо для повної ротації сівозміни.

Причиною безжального використання землі $€$ погоня землекористувачів за надвисокими прибутками, що стало можливим в Україні через відсутність дієвого державного механізму регулювання сільськогосподарського землекористування, який сприяв би раціональному використанню землі та збереженню ґрунтів.

Сьогодні в Україні йдеться про зняття мораторію на продаж земель та відкриття ринку сільськогосподарських земель. Для фрормування цивілізованого ринку земель, метою якого є насамперед збереження родючості для майбутніх поколінь, необхідно розробити низку нормативно-правових актів, що будуть зобов'язувати сільськогосподарських товаровиробників раціонально використовувати землю.

Пропонуємо запровадити систему державного контролю за станом родючості ґрунтів спеціальними державними органами (наприклад, агрохімічними інспекціями). Таке агрохімічне обстеження має здійснюватися регулярно 3 певною періодичністю і без повідомлення власника чи землекористувача.

Також на державному рівні слід закріпити обов'язок землекористувачів дотримуватися раціонально обґрунтованих сівозмін. При цьому в структурі посівних площ частка виснажливих культур не повинна перевищувати 15\%, за дотриманням чого також мають стежити відповідні державні органи.

Окрім цього, всі хімічні засоби, що застосовуються в рослинництві, мають пройти сертифрікацію та отримати відповідне екологічне маркування про те, що вони не є шкідливими для ґрунтів та сільськогосподарських тварин і комах.

Запровадження відповідних нормативно-правових актів щодо раціонального використання та збереження родючості земель є першочерговим завданням напередодні відкриття ринку земель в Україні.

Висновки 3 проведеного дослідження. Аналіз ефективності вирощування олійних культур показав, що виробництво цих культур $€$ ефективним, як в окремому підприємстві, так і загалом в Україні. Однак, останнім часом намітилася тенденція до зниження показників ефективності, зокрема рівня рентабельності. Однією з причин цього є погіршення родючості, що відбулося внаслідок нераціонального використання земель вітчизняними землекористувачами, зокрема перевищення над рекомендованими нормами частки виснажливих культур у структурі посівних площ, недотримання сівозмін. У таких умовах для підтримання досягнутого рівня та подальшого підвищення урожайності товаровиробники повинні були вносити більші дози мінеральних добрив, що, по-перше, впливає на рівень забрудненості 
земель, а по-друге, впливає на підвищення собівартості, внаслідок чого рівень рентабельності знизився. Таким чином, для вирішення дилеми одночасного підвищення ефрективності виробництва олійних культур та збереження родючості слід запровадити систему державного контролю за станом родючості ґрунтів. Такий контроль повинен здійснюватися спеціальними державними органами регулярно з певною періодичністю і без повідомлення власника чи землекористувача.

Також на державному рівні слід закріпити обов'язок землекористувачів дотримуватися раціонально обґрунтованих сівозмін. При цьому в структурі посівних площ частка виснажливих культур не повинна перевищувати 15\%, за дотриманням чого також мають стежити відповідні державні органи.

Окрім цього, всі хімічні засоби, що застосовуються в рослинництві, мають пройти сертифрікацію та отримати відповідне екологічне маркування про те, що вони не $є$ шкідливими для ґрунтів та сільськогосподарських тварин і комах.

Запровадження відповідних нормативно-правових актів щодо раціонального використання та збереження родючості земель $є$ першочерговим завданням напередодні відкриття ринку земель в Україні.

\section{БІБЛІОГРАФІЧНИЙ СПИСОК:}

1. Загальна характеристика олійних культур. Буковинська бібліотека : веб-сайт. URL: https:// buklib.net/books/30330/ (дата звернення: 15.10.2019).

2. Антонюк О.П. Аналіз тенденції виробництва та переробки насіння соняшнику в Україні. Економіка харчової промисловості. 2014. № 1. С. 50-53.

3. Бахчиванжи Л.А., Дяченко Л.Е., Почколіна С.В. Сучасний стан та перспективи виробництва соняшника в Україні. Вісник соціально-економічних досліджень. 2013. № 4(51). С. 9-14.

4. Олійні. Український клуб аграрного бізнесу: вебсайт. URL: http://ucab.ua/ua/doing_agribusiness/agrarni_ rinki/oliyni. (дата звернення: 16.10.2019).

5. Маслак О.М. Поточний стан та перспективи ринку соняшнику Агробізнес сьогодні. 2017. № 20(363). C. 12-20. URL: http://agro-business.com.ua/ agro/ekonomichnyi-hektar/item/8977-potochnyi-stan-taperspektyvy-rynku-soniashnyku.html (дата звернення: 19.10.2019)

6. Сільське господарство України. 2018 : статистичний збірник / Державна служба статистики України. Київ, 2019. С. 26-29.

7. Україна у цифррах. 2018 : статистичний збірник / Державна служба статистики України. Київ, 2019. C. 79-107.

8. Троценко В.І. Соняшник: Селекція, насінництво, технологія вирощування : монограсрія. Суми : Університетська книга, 2001. 184 с.

\section{REFERENCES:}

1. Bukovynsjka biblioteka. Zaghaljna kharakterystyka olijnykh kuljtur [General characteristics of oilseeds]. Available at: https://buklib.net/books/30330/ (accessed 15 October 2019).

2. Antonjuk O.P. (2014) Analiz tendenciji vyrobnyctva ta pererobky nasinnja sonjashnyku v Ukrajini [Analysis of the trend of production and processing of sunflower seeds in Ukraine]. Ekonomika kharchovoji promyslovosti, no. 1, pp. 50-53.

3. Bakhchyvanzhy L.A., Djachenko L.E., Pochkolina S.V. (2013) Suchasnyj stan ta perspektyvy vyrobnyctva sonjashnyka v Ukrajini [Current status and prospects of sunflower production in Ukraine]. Visnyk socialjnoekonomichnykh doslidzhenj, no. 4(51), pp. 9-14.

4. Ukrayinsyy klub ahrarnoho biznesu (2019) Olijni [Oilseeds]. Available at: http://ucab.ua/ua/doing_agribusiness/agrarni_rinki/oliyni (accessed 16 October 2019).

5. Maslak O.M. (2017) Potochnyj stan ta perspektyvy rynku sonjasnyku [Current status and outlook for the sunflower market]. Aghrobiznes sjoghodni (electronic journal), no. 20(363), pp. 12-20. Available at: http://agro-business.com.ua/agro/ekonomichnyi-hektar/item/8977-potochnyi-stan-ta-perspektyvy-rynkusoniashnyku.html (accessed 19 October 2019).

6. Derzhavna sluzhba statystyky Ukrajiny (2019) Siljsjke ghospodarstvo Ukrajiny 2018 [Agriculture of Ukraine 2018], Kyiv: Derzhanalitinform.

7. Derzhavna sluzhba statystyky Ukrajiny (2019) Ukrajina u cyfrakh 2018 [Ukraine in figures 2018], Kyiv: Derzhanalitinform.

8. Trocenko V.I. (2001) Sonjashnyk: Selekcija, nasinnyctvo, tekhnologhija vyroshhuvannja [Sunflower: Selection, seedproduction, technology of cultivating]. Sumy: Universytetsjka knygha. (in Ukrainian) 
Kovalova Olha

Candidate of Economic Sciences, Associate Professor, Senior Lecturer at Department of Economics and Entrepreneurship Sumy National Agrarian University

Kravchenko Karina

Master's Degree Seeking Applicant Sumy National Agrarian University

Pshykalo Vjacheslav

Master's Degree Seeking Applicant Sumy National Agrarian University

\section{THE DILEMMA OF THE EFFICIENCY OF OIL CROPS CULTIVATION AND SUSTAINING THE PRODUCTIVITY IN THE CONDITIONS OF THE LAND MARKET FORMATION}

The purpose of the article. Oilseeds are of great nutritional and technical importance. They are used as a food product in kind, for the manufacture of margarine, in the canning, food and confectionery industries. Due to the large economic, agro-technical and economic importance of oilseeds, the demand for these crops has increased significantly in recent years and has led to high prices for these seeds in Ukraine, which ensures high incomes of farmers and foreign currency to Ukraine. However, the question of further improving the efficiency of oilseed production, especially sunflower, and preserving the fertility of the land remains urgent.

Methodology. The basis of theoretical and methodological approaches to the study is based on the dialectical-materialistic method of cognition and systematic approach to the study of economic processes in the conditions of formation of the agricultural land market. The study was performed using abstract-logical, morphological, economic-statistical and rank methods.

Results. An analysis of the efficiency of growing oilseeds has shown that their production is effective, both in a single enterprise and in Ukraine as a whole. However, there has been a recent trend of declining performance indicators, including profitability. One of the reasons for this is the deterioration of fertility due to the irrational use of land by domestic land users, in particular, the excess of the share of depleting crops in the structure of acreage over the recommended norms, failure to observe crop rotation. That being the case, to maintain the achieved level and to further increase the yield, producers had to apply larger doses of mineral fertilizers and growth-regulating chemicals, which firstly may affect the level of land pollution and, secondly, increases the cost, resulting in a decreased profitability. Thus, in order to resolve the dilemma of improving the efficiency of oilseeds production and preserving fertility, a state control system for soil fertility should be introduced. Such controls should be carried out regularly by the special state bodies at regular intervals and without notification to the owner or land user.

It is also important to enshrine at the statutory level the necessity to comply with rationally justified crop rotations for the land users. In the structure of sown areas share depleting crops must not exceed $15 \%$, this should also be followed by the relevant public authorities.

In addition, all chemicals used in crop production must be certified and properly labelled for their harm to soil and farm animals and insects.

The introduction of appropriate regulations on the rational use and conservation of land fertility is a priority before the creation of the land market in Ukraine.

Practical implications. Results of the study are of practical importance in the emerging market of agricultural land. In particular, introduction of a mechanism of state control over the quality of land, control over the process of land use by agricultural producers by state bodies, introduction of a system of certification and marking of all chemicals used in agriculture will create certain "rules of conduct" for land use after the lifting of the moratorium on the sale and introduction of the agricultural land market.

Value/originality. The analysis presented showed the problem of inconsistency between the issue of further increase of profitability of agricultural activity and the need to preserve land, which becomes especially relevant in the conditions of land market formation, and outlines the prospects for further research in order to develop an effective mechanism for promoting rational land use. 